https://doi.org/10.25208/0042-4609-2019-95-5-17-23

$\mathrm{P}$

аспределение меланоцитов в коже больных псориазом

Жуков А. С. ${ }^{*}$, Хайрутдинов В. Р., Белоусова И. Э., Самцов А. В.

Военно-медицинская академия им. С. М. Кирова Министерства обороны Российской Федерации 194044, Российская Федерация, г. Санк т-Петербург, ул. Академика Лебедева, д. 6

Псориаз является хроническим иммуноопосредованным воспалительным заболеванием с преимущественным поражением кожи и суставов. Несмотря на фундаментальные исследования его патогенеза, на настоящий момент не определена причина развития Т-клеточного ответа. Сравнительно недавно была предложена новая концепция фрормирования псориатического воспаления, где значимую роль в патогенезе отводят меланоцитам. Оценка содержания данных клеток и их взаимосвязи с другими структурами позволит расширить представление о патогенезе псориаза и мишенях таргетной терапии.

Цель: изучение количества, распределения и пролиферативной активности меланоцитов в коже больных псориазом.

Материалы и методы. В исследование было включено 20 больных бляшечным псориазом: мужчин - 18 (90 \%), женщин - 2 (10 \%). Тяжесть заболевания оценивалась по индексу площади и тяжести псориатических поражений PASI. В гистологических препаратах определяли толщину эпидермиса, длину базальной мембраны в поле зрения, а также патоморфологические изменения в эпидермисе и дерме. Для иммуногистохимической детекции меланоцитов использовали маркер MelanA, пролиферативной активности клеток - Ki67, цитотоксических Т-лимфоцитов - CD8. Применяли двойную систему визуализации. Достоверным считали различия при $p<0,05$.

Результаты. Количество MelanA+-клеток в пораженной коже больных псориазом - 54 (44-64)/1,4 мм² было в 2,4 раза выше, чем в непораженной коже, - 24 (22-30)/1,4 мм² $(p<0,05)$, и в 2 раза выше, чем в коже здоровых лиц, - $27(25-32) / 1,4$ мм² $^{2}(p<0,05)$. Содержание MelanA+-клеток на 1 мм базальной мембраны у больных псориазом в пораженной коже - 11 [7-13] клеток/мм, непораженной 12 [11-14] клеток/мм и у здоровых лиц - 12 [9-13] клеток/мм значимо не отличалось $(p>0,05)$. В пораженной коже больных псориазом выявлены множественные контакты CD8 ${ }^{+}$- и MelanA ${ }^{+}$-клеток $10[8-13] / 1,4 \mathrm{MM}^{2}$.

Выводы. В пораженной коже больных псориазом абсолютное количество меланоцитов было значительно выше, чем в непораженной коже и коже здоровых лиц, в то время как соотношение меланоцитов к базальным кератиноцитам не отличалось. В коже всех исследуемых групп не выявлены меланоциты в стадии пролиферации. Наблюдались множественные контакты MelanA+ ток в пораженной коже больных псориазом.

Ключевые слова: псориаз, меланоциты, цитотоксические Т-лимфоциты, патогенез, MelanA, CD8

Конфрликт интересов: авторы заявляют об отсутствии потенциального конфликта интересов, требующего раскрытия в данной статье.

Для цитирования: Жуков А. С., Хайрутдинов В. Р., Белоусова И. Э., Самцов А. В. Распределение меланоцитов в коже больных псориазом. Вестник дерматологии и венерологии. 2019;95(5):17-23. https://doi.org/10.25208/00424609-2019-95-5-17-23 


\title{
Distribution of melanocytes in the skin of psoriasis patients
}

\author{
Aleksander S. Zhukov*, Vladislav R. Khairutdinov, Irena E. Belousova, Aleksey V. Samtsov
}

S. M. Kirov Military Medical Academy, Ministry of Defence of the Russian Federation

Akademika Lebedeva str., 6, Saint Petersburg, 194044, Russian Federation

Psoriasis is a chronic immune-mediated inflammatory disease with predominant damage to the skin and joints. Despite fundamental studies of its pathogenesis, the cause of the development of the T-cell response has not been determined. More recently, a new concept has been proposed for the formation of psoriatic inflammation, where a significant role in the pathogenesis is assigned to melanocytes. Evaluation of the content of these cells and their relationship with other participants of inflammation will allow expanding the understanding of the pathogenesis of psoriasis and the targets of targeted therapy.

Aim: study of the quantity, distribution and proliferative activity of melanocytes.

Materials and methods. The study included 20 patients with plaque psoriasis: men - 18 (90\%), women $2(10 \%)$. The severity of the disease was assessed by the index of the area and severity of PASI psoriatic lesions. In the histological specimens, the thickness of the epidermis, the length of the basement membrane in the visual field, and pathological changes in the epidermis and dermis were determined. For immunohistochemical detection of melanocytes, the MelanA marker was used, the cell proliferative activity was Ki67, and the cytotoxic T-lymphocytes, CD8. Used a dual visualization system. Differences were considered significant at $p<0.05$.

Results. The number of MelanA ${ }^{+}$cells in the affected skin of patients with psoriasis $-54(44-64) / 1.4 \mathrm{~mm}^{2}$ was 2.4 times higher than in unaffected skin $-24(22-30) / 1.4 \mathrm{~mm}^{2}(p<0.05)$, and 2 times higher than in the skin of healthy individuals $-27(25-32) / 1.4 \mathrm{~mm}^{2}(p<0.05)$. The content of MelanA ${ }^{+}$cells per $1 \mathrm{~mm}$ of the basement membrane in patients with psoriasis in the affected skin is 11 [7-13] cells $/ \mathrm{mm}$, unaffected - 12 [11-14] cells $/ \mathrm{mm}$ and in healthy individuals - 12 [9-13] cells $/ \mathrm{mm}$ did not significantly differ $(p>0.05)$. In the affected skin of patients with psoriasis, multiple contacts of $\mathrm{CD}^{+}$and MelanA ${ }^{+}$cells were detected $-10[8-13] / 1.4 \mathrm{~mm}^{2}$.

Conclusions. In the affected skin of patients with psoriasis, the absolute number of melanocytes is significantly higher than in unaffected skin and the skin of healthy individuals, while the ratio of melanocytes to basal keratinocytes did not differ. In the skin of all the studied groups, no melanocytes in the proliferation stage were detected. Multiple contacts of $\mathrm{MelanA}^{+}$and $\mathrm{CD}^{+}$cells are observed in the affected skin of patients with psoriasis.

\section{Keywords: psoriasis, melanocytes, cytotoxic T-lymphocytes, pathogenesis, MelanA, CD8}

Conflict of interest: the authors state that there is no potential conflict of interest requiring disclosure in this article.

For citation: Zhukov A. S., Khairutdinov V. R., Belousova I. E., Samtsov A. V. Distribution of melanocytes in the skin of psoriasis patients. Vestnik Dermatologii i Venerologii. 2019;95(5):17-23. https://doi.org/10.25208/0042-4609-2019-955-17-23 
Псориаз является хроническим мультифакториальным иммуноопосредованным воспалительным заболеванием с преимущественным поражением кожи и суставов.

Роль наследственности в развитии болезни очевидна и подтверждается близнецовым и генеалогическим методами исследования. Установлены ассоциации псориаза с генами, участвующими в развитии воспалительного процесса, регуляции продукции цитокинов и защите от микроорганизмов [1]. Вклад генов, кодирующих белки I класса главного комплекса гистосовместимости (человеческие лейкоцитарные антигены - HLA), по данным некоторых авторов, составляет 30-50\% генетического компонента заболевания [1]. Например, наличие аллеля HLA-C*06:02 связано с повышением риска возникновения псориаза в несколько раз, ранним началом, тяжелым течением болезни, а также более выраженным терапевтическим эффектом при проведении генно-инженерной биологической терапии [2-5].

Молекулы I класса HLA экспрессируются на вcех ядерных клетках и участвуют в процессинге антигенов и их детекции CD8+-T-лимсроцитами. При нарушении распознавания собственных антигенов Т- и В-лимфоцитами происходит развитие аутоиммунной реакции. Для CD8 ${ }^{+}$-Т-лимфоцитов характерны цитотоксические свойства, обуславливающие их участие в уничтожении опухолевых или инфиццированных клеток [6].

В эпидермисе больных псориазом наблюдается многократное увеличение количества $\mathrm{CD}^{+}{ }^{-}$-клеток с высокой степенью олигоклональности, что в совокупности с определенным цитокиновым профилем экспрессии может указывать на аутоиммунный процесс. Эфрфективность терапии местными и системными иммуносупрессивными препаратами подтверждает данную теорию [6].

В качестве вероятных аутоантигенов при псориазе рассматриваются различные белковые соединения: кателицидин (LL-37) и $\beta$-дефензины из группы антимикробных пептидов; фосфолипаза А2 - фермент, участвующий в образовании свободных жирных кислот; кератины К16 и К17, гомологичные М-протеину стрептококка [2]. Относительно недавно группа исследователей выявила новый клеточный антиген. В данной работе было показано, что в эпидермисе больных псориазом CD8 ${ }^{+}-$клетки взаимодействуют с белком ADAMTSL5 (A Disintegrin-like and Metalloprotease domain containing Thrombospondin Type 1 motif-like 5 - белок, участвующий в функционировании микрофибрилл клеток), расположенным в меланоцитах, инициируя развитие аутоиммунной реакции [7].

В другом исследовании было показано, что белок ADAMTSL5 экспрессируется не только меланоцитами, но также кератиноцитами и эндотелиальными клетками сосудов дермы. Выраженная экспрессия данного белка кератиноцитами может объясняться его синтезом в самих кератиноцитах или его трансфером в кератиноциты из меланоцитов с помощью меланосом. Установлено, что в пораженной коже больных псориазом на участках с высокой экспрессией белка ADAMTSL5 отмечалась наибольшая концентрация Т-лимфоцитов и дендритных клеток [8].

Несмотря на относительную новизну данной теории, уже проведены первые лабораторные исследования препарата, где мишенью являлся меланоцит. На мышиной модели псориаза применяли топический препарат, содержащий а-меланоцит-стимулирующий гормон (индуцирует синтез меланина в меланоцитах). Отмечалось выраженное уменьшение воспалительных изменений в коже и нормализация клинических и гистологических показателей [8].

Таким образом, оценка численности, распределения и функционального состояния меланоцитов может представлять научный интерес для более глубокого понимания патогенеза псориаза.

Цель исследования - изучение количества, распределения и пролиферативной активности меланоцитов в коже больных псориазом.

\section{Материалы и методы исследования}

В исследование было включено 20 больных бляшечным псориазом: мужчин - 18 (90\%), женщин 2 (10\%), находящихся на лечении в клинике кожных и венерических болезней Военно-медицинской академии им. С.М. Кирова. В качестве контроля изучали группу 10 здоровых доноров, не имеющих псориаза в анамнезе: мужчин - 7 (70\%), женщин - 3 (30\%). Тяжесть болезни оценивалась по индексу площади и тяжести псориатических поражений PASI (Psoriasis Area and Severity index): легкая степень - <10 баллов, средняя степень - $\geq 10$ и <20 баллов, тяжелая степень $\geq 20$ баллов. Легкая степень тяжести определялась у 4 больных (20\%, средняя - 14 (70\%), тяжелая у 2 (10\%). Все пациенты подписали информированное согласие на участие в исследовании. Получено разрешение независимого этического комитета при ВМедА им. С.М. Кирова (№ 221 от 23 апреля 2019 г.).

Объектами исследования были пораженные (папулы, бляшки) и непораженные (более 5 см от высыпаний) участки кожи больных псориазом и здоровых лиц, взятые методом инцизионной биопсии. Инцизионная биопсия проводилась с помощью хирургического скальпеля и одноразовых стерильных лезвий № 11 (Surgical blade, Нидерланды) с использованием инфильтрационной анестезии $2 \%$ раствором лидокаина. Исследуемый материал фриксировался в забуференном (фоссратном) $10 \%$ нейтральном фрормалине, проводили по восходящим спиртам (70, 80, 90 и 100 \%) в аппарате гистологической проводки тканей Leica Peloris (Leica Microsystem, Германия), заливали в парафин. После получения парафиновых блоков кожи из них готовили срезы для гистологического и иммуногистохимического исследования.

Гистологическое исследование проводилось при окрашивании срезов парафиновых блоков гематоксилином-эозином. В световом микроскопе Olympus BX-51 (Япония), оборудованном цифровой камерой Olympus XC-10 и программным обеспечением Cell A, на увеличении $\times 100, \times 200$ и ×400 исследовали эпидермис и дерму. В гистологических препаратах определяли толщину эпидермиса, длину базальной мембраны в поле зрения, а также патоморфологические изменения в эпидермисе и дерме.

Морфометрическое исследование кожи проводили при увеличения $\times 100$ и ×200. Перед началом исследования выполняли калибровку с помощью объект-микрометра. В каждом препарате толщина эпидермиса и длина базальной мембраны была измерена пять раз в полях зрения с наиболее выраженными изменениями. Полученные данные представлены в виде среднего значения (медианы) показателя для каждого препарата. 
Для иммуногистохимической детекции меланоцитов использовали маркер MelanA, пролиферативной активности клеток - Кі-67, цитотоксических Т-лимфоцитов - CD8 (табл. 1). Применяли двойную систему визуализации (Abcam, США). Данная система позволяет визуализировать взаимное расположение двух разных антигенов в одном препарате. Она состоит из смеси антивидовых антител и двух разных хромогенов: щелочная фоссратаза (AP/Red) при расщеплении своего хромогена дает красное окрашивание, диаминобензидин (DAB) - коричневое.

Определение количества окрашенных цветовой меткой (позитивных) клеток выполняли при увеличении $\times 100$ светового микроскопа в трех полях зрения (размерами $1392 \times 1013$ мкм = 1,4 мм²), выбранных с учетом наибольшего количества меченых клеток, используя компьютерную программу анализа изображения ImageTool 3.0 (UTHSCSA, CША). Полученные данные заносили в базу данных в виде медианы (верхнего и нижнего квартилей) числа позитивных клеток в поле зрения, посчитанных для каждого биоптата.

Статистическая обработка данных проводилась с использованием программы Statistica 10.0 (StatSoft, Inc). Для сравнения данных между группами применяли $U$-критерий Манна - Уитни. Достоверным считали различия при $p<0,05$. Для выявления взаимосвязи между показателями использовали коэффрициент Спирмена. Корреляцию оценивали значимой при уровне $p<0,05$. Тесноту связи между признаками считали слабой при $r<0,3$, умеренной - при 0,3 $\leq r<0,7$, сильной - при $r \geq 0,7$.

\section{Результаты исследования}

При проведении гистологического исследования установлено, что толщина эпидермиса пораженной кожи больных псориазом - 416 [406-430] мкм в 5,1 раза больше, чем непораженной, - 82 [74117] мкм $(p<0,05)$ и в 4,6 раза больше, чем кожа здоровых лиц, - 90 (72-96) мкм $(p<0,05)$ (табл. 2). Толщина эпидермиса в непораженной и здоровой коже значимо не отличалась $(p>0,05)$. Длина базальной мембраны пораженной кожи - 5330 [4514-6941] мкм/1,4 мм² в 2,6 раза превышает данный показатель в непораженной - 2043 [1929-2410] мкм/1,4 мм² $(p<0,05)$ и в 2,1 раза у здоровых лиц - 2545 [2108-2679] мКм/1,4 мм² $(p<0,05)$ (рис. 1А, Б, В).

В ходе анализа тканевого распределения MelanA+клеток установлено, что они локализовались на базальной мембране между кератиноцитами (в том числе в наружном корневом влагалище волосяных фролликулов) и имели морфологию меланоцитов. Количество MelanA ${ }^{+}$-клеток в пораженной коже больных псориазом - 54 [44-64]/1,4 мм² - было в 2,4 раза выше, чем в непораженной коже, $-24[22-30] / 1,4$ мм $^{2}(p<0,05)$, и в 2 раза выше, чем в коже здоровых лиц, - 27 [25-32]/1,4 мм $^{2}(p<0,05)$. Количество MelanA ${ }^{+}$-клеток на 1 мм базальной мембраны у больных псориазом в пораженной коже составило 11 [7-13] кл./мм, непораженной - 12 [11-14] кл./мм и у здоровых лиц 12 [9-13] кл./мм, что значимо не отличалось $(p>0,05$ при каждом попарном сравнении) (рис. 1Г, Д, Е).

Количество CD8 ${ }^{+}$-клеток в эпидермисе пораженной кожи больных псориазом - 32 [19-40]/1,4 мм² - было в 32 раза выше, чем в непораженной, - 1 [0-2]/1,4 мм² $(p<0,05)$, а в дерме пораженной кожи данный показатель - 105 [66-131]/1,4 мм² - в 8,1 раза выше, чем в непораженной, - $13[12-33] / 1,4$ мм² $^{2}(p<0,05)$. У здоровых лиц экспрессии маркера CD8 в эпидермисе практически не наблюдалось, в дерме - 10 [7-16]/1,4 мм² - значимо

Таблица 1. Гистологическая и иммуногистохимическая характеристика изучаемых групп

Table 1. Histological and immunohistochemical characteristics of the studied groups

\begin{tabular}{|c|c|c|c|c|c|}
\hline Антиген & Антитело (клон) & Хозяин антител & Разведение антител & Способ демаскировки антигена & Производитель антител \\
\hline MelanA & A103 & Мышь & 1:100 & трис-эдта буфер, ${ }_{\text {p }} \mathrm{H}$ 9,0 & Abcam, США \\
\hline CD8 & SP57 & Кролик & $1: 50$ & трис-эдта буфрер, ${ }_{\mathrm{p}} \mathrm{H}$ 9,0 & Ventana, США \\
\hline Ki-67 & SP6 & Кролик & 1:150 & трис-эдта буфер, ${ }_{\mathrm{p}} \mathrm{H}$ 9,0 & Ventana, США \\
\hline
\end{tabular}

Таблица 2. Гистологическая и иммуногистохимическая характеристика изучаемых групп

Table 2. Histological and immunohistochemical characteristics of the studied groups

\begin{tabular}{|c|c|c|c|}
\hline & Псориаз (пораженная кожа) & Псориаз (непораженная кожа) & Здоровые лица \\
\hline Толщина эпидермиса, мкм & $416[406-430]^{\star \S}$ & 90 [72-96] & $82[74-117]$ \\
\hline Длина базальной мембраны/1,4 мм², мкм & $5330[4514-6941]^{\star \S}$ & 2043 [1929-2410] & 2545 [2108-2679] \\
\hline MelanA+-клетки/1,4 мм² & $54[44-64]^{\star \S}$ & 24 [22-30] & 27 [25-32] \\
\hline MelanA+-клетки/мм базальной мембраны & $11[7-13]$ & $12[11-14]$ & $12[9-13]$ \\
\hline MelanA+-Ki-67+-клетки/1,4 мм² & $0[0-1]$ & $0[0-0]$ & $0[0-0]$ \\
\hline $\begin{array}{c}\text { CD8+-клетки } / 1,4 \text { мм²: } \\
\text { - в эпидермисе } \\
\text { - в дерме }\end{array}$ & $\begin{array}{r}32[19-40]^{\star \S} \\
105[66-131]^{\star \S}\end{array}$ & $\begin{array}{c}1[0-2] \\
13[12-33]\end{array}$ & $\begin{aligned} 0 & {[0-0] } \\
10 & {[7-16] }\end{aligned}$ \\
\hline 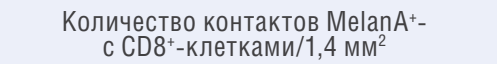 & $10[8-13]^{\star \S}$ & $0[0-1]$ & $0[0-1]]$ \\
\hline
\end{tabular}

Примечание: * — $p<0,05$ при сравнении с группой здоровых лиц; ${ }^{\S}-p<0,05$ при сравнении с группой больных псориазом (непораженная кожа); все значения представлены в виде M [IQR], где M — медиана; IQR — верхний и нижний квартили.

Note: * $-p<0.05$ when compared with the group of healthy individuals; ${ }^{\S}-p<0.05$ when compared with the group of psoriasis patients (unaffected skin); all values are presented as $\mathrm{M}[\mathrm{IQR}]$, where $\mathrm{M}$ is the median; IQR is the upper and lower quartiles. 

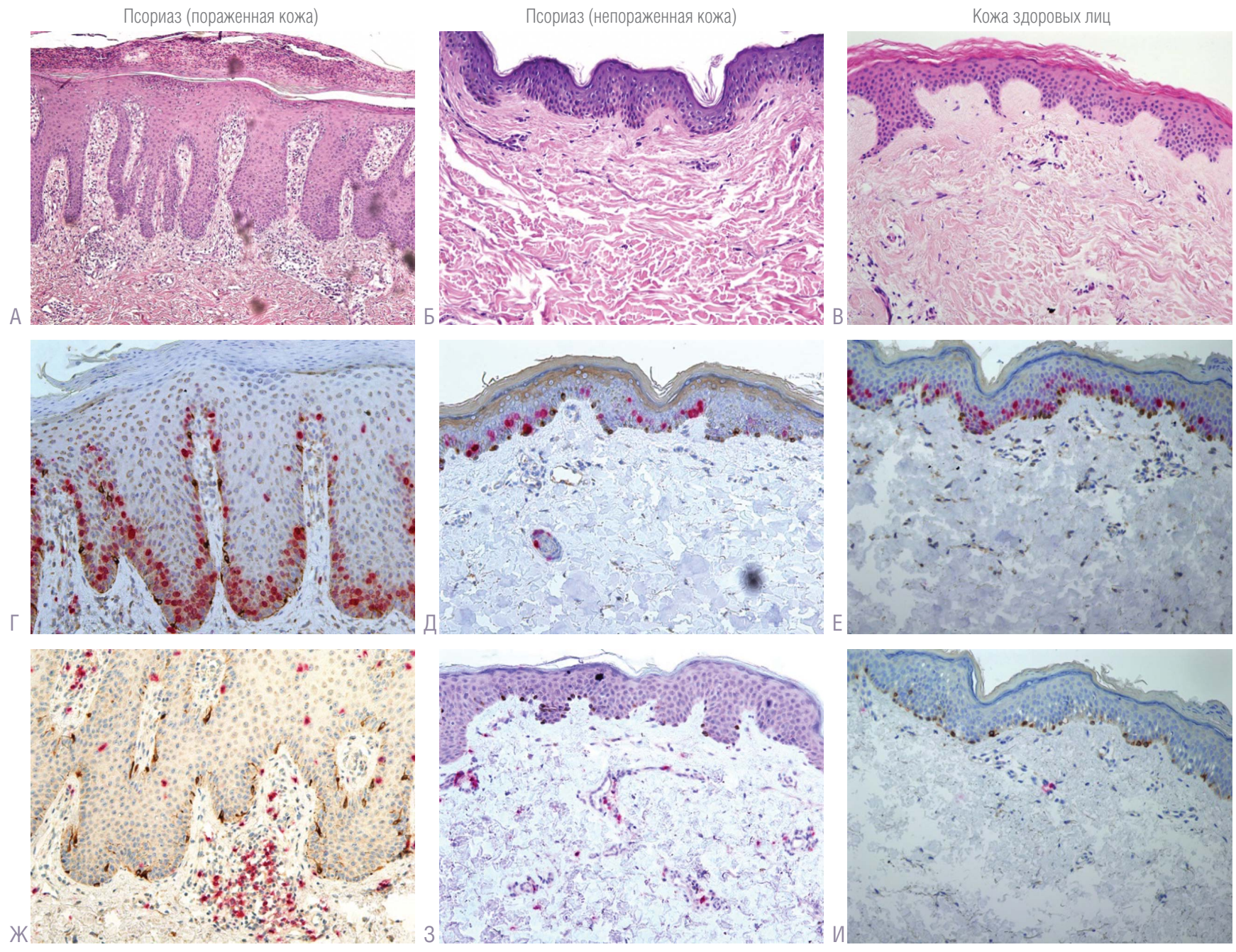

\footnotetext{
Рис. 1. А, Б, В - гистологическое исследование (окраска гематоксилином и эозином); ув. х100; Г, Д, Е - иммуногистохимическое исследование (двойная система детекции): красное окрашивание - маркер Ki-67, коричневое — маркер MelanA); ув. ×200, 696×507 мкм; Ж З 3, И — иммуногистохимическое исследование (двойная система детекции: красное окрашивание - маркер CD8, коричневое — маркер MelanA); ув. ×200, 696×507 мкм

Fig. 1. A, Б, B - histological examination (stained with hematoxylin and eosin); magn. $x 100 ; Г, ~ Д, E-$ immunohistochemical study (dual detection system): neutral red

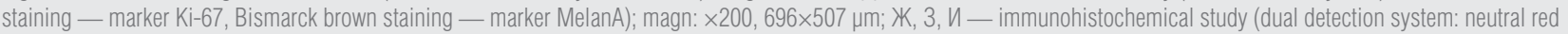
staining — marker CD8, Bismarck brown staining — marker MelanA); magn. ×200, 696×507 $\mu \mathrm{m}$
}

не отличалось от значения в интактной коже больных псориазом - 13 [12-33]/1,4 мм² $(p>0,05)$ (рис. 1Ж, 3, И).

В пораженной коже больных псориазом выявлены множественные контакты $\mathrm{CD8}^{+}$- и MelanA+-клеток 10 [8-13]/1,4 мм² (рис. 2). В непораженной коже и коже здоровых лиц контакты CD8 ${ }^{+}$- и MelanA ${ }^{+}$-клеток практически не наблюдались - 0 [0-1].

В эпидермисе больных псориазом в области высыпаний были обнаружены единичные пролиферирующие MelanA ${ }^{+}-\mathrm{Ki}-67^{+}-$клетки - 0 [0-1] (рис. 3).

При корреляционном анализе у больных псориазом выявлена умеренная прямая связь между количеством CD8+-клеток дермы и толщиной эпидермиса $(r=0,65, p<0,05)$, количеством CD8+-клеток эпидермиca $(r=0,66, p<0,05)$; сильная прямая связь между количеством контактов CD8 ${ }^{+}$и MelanA ${ }^{+}$-клеток и длиной базальной мембраны в поле зрения $(r=0,71, p<0,05)$.

\section{Обсуждение}

Функция меланоцитов не ограничивается только продукцией меланина. Эти клетки происходят из нерв- ного гребня, сохраняют взаимосвязь с нервными окончаниями и способны продуцировать нейропептиды. Роль нервной системы в развитии псориаза очевидна. Нервно-психический стресс является одним из триггерных фракторов заболевания. В пораженной коже больных отмечается выраженное увеличение количества нервных волокон, уровня субстанции $\mathrm{P}$, вазоактивных интестинальных и кальцитотин-связанных пептидов [10]. Важной особенностью меланоцитов является их способность к взаимодействию за счет своих отростков с окружающими кератиноцитами (меланоцит-эпидермальная единица). Меланоциты контролируют гомеостаз кальция в кератиноцитах, снижая их избыточную пролиферативную активность, а также защищают от повреждающего действия активных соединений кислорода [11]. Тесная взаимосвязь меланоцитов с кератиноцитами также обусловлена транспортом находящегося в меланосомах меланина посредством экзоцитоза, цитофагоцитоза, слияния цитоплазматической мембраны и мембранных пузырьков [12]. Меланоциты - важный компонент иммунной системы. Экспрессируя на своей 


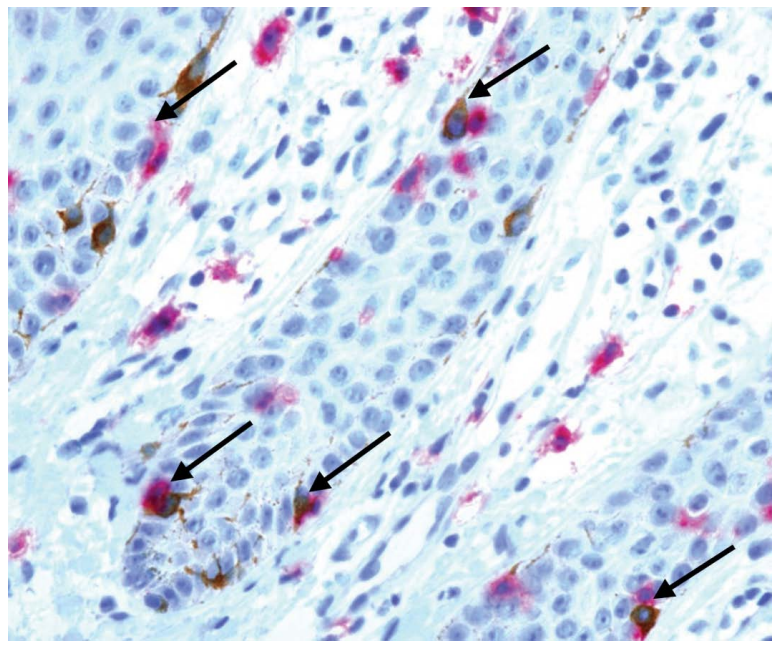

Рис. 2. Иммуногистохимическое исследование (двойная система детекции). Контакты MelanA+-клеток (коричневое окрашивание) и CD8+-клеток (красное окрашивание) в эпидермисе (отмечено стрелками); ув. ×400, 348×253 мкм Fig. 2. Immunohistochemical study (dual detection system). The contacts of MelanA+cells (Bismarck brown staining) and CD8 $8^{+}$cells (neutral red staining) in the epidermis (marked by arrows); magn. $\times 400,348 \times 253 \mu \mathrm{m}$

поверхности молекулы главного комплекса гистосовместимости 2-го класса (HLA II - человеческие лейкоцитарные антигены), они являются антигенпрезентирующими клетками, способными инициировать развитие адаптивного иммунного ответа [13, 14].

В нашей работе установлено увеличение абсолютного количества меланоцитов в пораженной коже больных псориазом по сравнению с кожей здоровых лиц. При сравнении содержания меланоцитов на 1 мм базальной мембраны не выявлено значимых различий между всеми исследуемыми группами, т.е. соотношение количества меланоцитов и базальных кератиноцитов было одинаковым. В то же время при развитии псориатических высыпаний за счет фрормирования эпидермальных выростов происходит удлинение базальной мембраны (в 2,1 раза), из чего следует вывод об увеличении количества меланоцитов в эпидермисе на единицу площади кожи.

Гиперплазия эпидермиса у больных псориазом обусловлена повышением пролиферативной активности базальных кератиноцитов. Установленное в нашей работе увеличение количества меланоцитов в поле зрения более чем в два раза также нуждается в объяснении. Для детекции пролиферации меланоцитов было проведено двойное иммуногистохимическое исследования с маркерами MelanA и Ki-67, позволяющее визуализировать пролиферирующие меланоцитарные клетки. MelanA ${ }^{+}-K \mathrm{i}-67^{+}-$клетки (двойные позитивные) в коже изучаемых групп практически не встречались, за исключением единичных клеток в пораженной коже больных псориазом. Таким образом, повышенное число меланоцитов не связано с делением этих клеток в эпидермисе, а, вероятно, происходит в утолщении (bulge, волосяная луковица) волосяного фролликула, где расположены герминативные клетки. В исследовании механизмов репигментации кожи при витилиго представлен предполагаемый механизм миграции предшественников меланоцитов из bulge зоны в межфолликулярный эпидермис [15].

Механизм активации Т-клеточного ответа при псориазе не определен. В то же время CD8+-клетки пред-

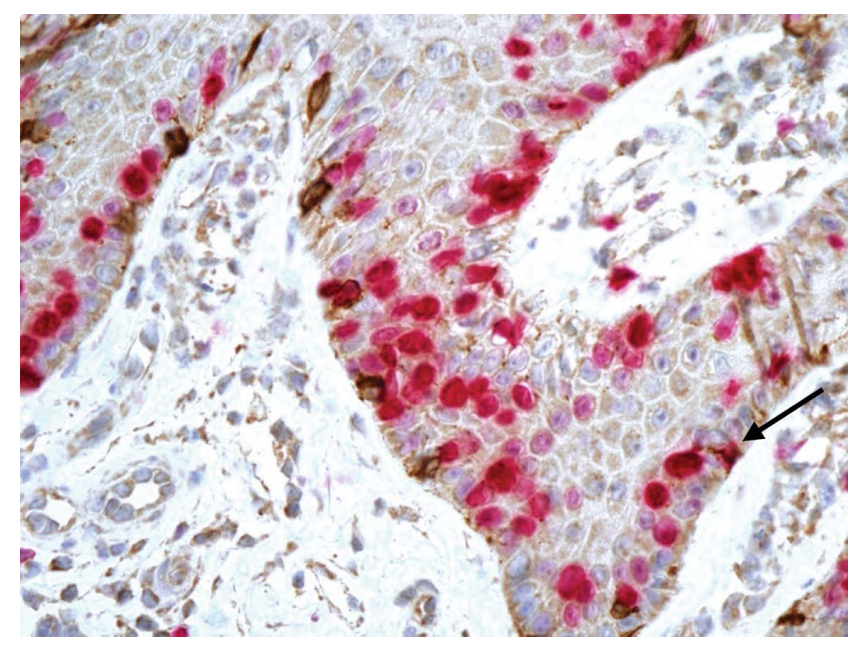

Рис. 3. Иммуногистохимическое исследование (двойная система детекции) Пролиферирующий меланоцит (MelanA+-Ki67+-клетка) в эпидермисе больных псориазом (отмечено стрелкой); ув. $\times 400,348 \times 253$ мкм Fig. 3. Immunohistochemical study (dual detection system). Proliferating melanocyte (MelanA ${ }^{+}-K i 67^{+}-$cell) in the epidermis of psoriasis patients (marked by an arrow); magn. $\times 400,348 \times 253 \mu \mathrm{m}$

ставляют основную субпопуляцию лимфоцитов эпидермиса у больных в прогрессирующем периоде псориаза. Их функция заключается во взаимодействии с другими клетками, на поверхности которых представлен комплекс HLA I типа с антигеном [6]. Для выявления характера межклеточного взаимодействия CD8+-клеток мы изучили тканевое распределение $\mathrm{CD}^{+}$- и MelanA ${ }^{+}$ клеток в одном срезе. Было установлено, что в пораженной коже больных псориазом наблюдается повышенное число контактов MelanA+- и CD8+-клеток, что может свидетельствовать о наличии иммунной реакции между данными клетками.

Повышение количества меланоцитов в пораженной коже больных псориазом и увеличение числа контактов с цитотоксическими Т-лимфоцитами позволяет предполагать возможную роль меланоцитов в иммунном ответе при псориазе. Нарушение транспорта белков, продуцируемых меланоцитами, может быть инициирующим фактором развития воспалительной реакции с последующей демаскировкой собственных антигенов и развитием аутоиммунного воспаления.

Представляет научный интерес изучение в коже больных псориазом уровня пролиферации и дифрференцировки стволовых клеток меланоцитов, характера распределения меланосом различной степени зрелости, а также роли белка ADAMTSL5 как активирующего антигена.

В нашей работе были подтверждены сведения о повышении абсолютного числа меланоцитов и их контактов с цитотоксическими лимфоцитами в пораженной коже больных псориаза. Кроме того, нами было впервые установлено, что соотношение меланоцитов к базальным кератиноцитам одинаково во всех исследуемых группах, а пролиферации меланоцитов практически не происходит.

\section{Выводы}

В пораженной коже больных псориазом абсолютное количество меланоцитов было значительно выше, чем в непораженной коже и коже здоровых лиц, 
в то время как соотношение меланоцитов к базальным кератиноцитам не отличалось. В коже всех исследуемых групп не выявлены меланоциты в стадии про- лиферации. Наблюдались множественные контакты

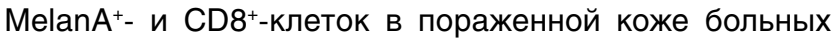
псориазом.

\section{Литература/References}

1. Aggarwal S., Nayek A., Pradhan D. et al. dbGAPs: A comprehensive database of genes and genetic markers associated with psoriasis and its subtypes. Genomics. 2017;(17):30115-30125.

2. Dand N., Duckworth M., Baudry D. et al. BADBIR Study Group; BSTOP Study Group; PSORT Consortium. HLA-C*06:02 genotype is a predictive biomarker of biologic treatment response in psoriasis. J Allergy Clin Immunol. 2019;143(6):2120-2130.

3. Хайрутдинов В. Р., Жуков А. С., Пономарев И. А. и др. Роль полиморсных генов программируемой клеточной гибели в формировании риска развития псориаза. Вестник дерматологии и венерологии. 2009;4:4-8. [Hairutdinov V. R., Zhukov A. S., Ponomarev I. A. et al. The role of apoptotic gene variations in psoriasis development. Vestnik Dermatologii i Venerologii. 2009;4:4-8. (In Russ.)]

4. Хайрутдинов В. Р. Генетический паспорт больного псориазом. Вестник дерматологии и венерологии. 2011;4:14-19. [Hairutdinov V. R. Genetic profile of psoriasis patients. Vestnik Dermatologii $\mathrm{i}$ Venerologii. 2011:4:14-19. (In Russ.)]

5. Mabuchi T., Ota T., Manabe Y. et al. HLA-C*12:02 is a susceptibility factor in late-onset type of psoriasis in Japanese. J Dermatol. 2014:41:697-704.

6. Prinz J. C. Human Leukocyte Antigen-Class I Alleles and the Autoreactive $\mathrm{T}$ Cell Response in Psoriasis Pathogenesis. Front Immunol. 2018;30(9):954-959.

7. Arakawa A., Siewert K., Stöhr J. et al. Melanocyte antigen triggers autoimmunity in human psoriasis. J Exp Med. 2015;212(13):2203-2212.

8. Bonifacio K. M., Kunjravia N., Krueger J. G., Fuentes-Duculan J. Cutaneous expression of a disintegrin-like and metalloprotease domain containing thrombospondin type 1 motif- like 5 (ADAMTSL5) in psoriasis goes beyond melanocytes. J Pigment Disord. 2016;3(3):515-521.

9. Shah P. P., Desai P. R., Boakye C. H. et al. Percutaneous delivery of $\alpha$-melanocyte-stimulating hormone for the treatment of imiquimod-induced psoriasis. J Drug Target. 2016;24(6):537-547.

10. Brajac I., Kastelan M., Prpić-Massari L. et al. Melanocyte as a possible key cell in the pathogenesis of psoriasis vulgaris. Med Hypotheses. 2009;73(2):254-256.

11. Tobin D. J., Paus R. Graying: Gerontobiology of the hair follicle pigmentary unit. Exp Gerontol. 2001;36(1):29-54.

12. Strassner J. P., Rashighi M., Harris J. E. Melanocytes in psoriasis: convicted culprit or bullied bystander? Pigment Cell Melanoma Res. 2016:29(3):261-263.

13. Nystedt $S$. Molecular cloning of a potential proteinase activated receptor. Proc Natl Acad Sci USA. 1994;91(20):9208-9212.

14. Scott G. Protease-activated receptor 2, a receptor involved in melanosome transfer, is upregulated in human skin by ultraviolet irradiation. J Invest Dermatol. 2001;117(6):1412-1420.

15. Yu S., Lan C. E., Yu H. S. Mechanisms of repigmentation induced by photobiomodulation therapy in vitiligo. Exp Dermatol. 2019 Feb;28 Suppl 1:10-14

\section{Информация об авторах}

Александр Сергеевич Жуков ${ }^{*}$ - к.м.Н., докторант кафредры кожных и венерических болезней Военно-медицинской академии им. С. М. Кирова Министерства обороны Российской Федерации; e-mail: doctor-vma@mail.ru

Владислав Ринатович Хайрутдинов - д.м.н., доцент, доцент кафедры кожных и венерических болезней Военно-медицинской академии им. С. М. Кирова Министерства обороны Российской Федерации; e-mail: haric03@list.ru

Ирена Эдуардовна Белоусова - д.м.н., доцент, профрессор кафедры кожных и венерических болезней Военно-медицинской академии им. С.М.Кирова Министерства обороны Российской Федерации; e-mail: irena.belousova@mail.ru

Алексей Викторович Самцов - д.м.Н., профессор, заведующий кафредрой кожных и венерических болезней Военно-медицинской академии им. С. М. Кирова Министерства обороны Российской Федерации; e-mail: avsamtsov@mail.ru

\section{Information about the authors}

Aleksander S. Zhukov* - Cand. Sci. (Med.), Doctoral Candidate, Department of Skin and Sexually Transmitted Diseases, S. M. Kirov Military Medical Academy, Ministry of Defence of the Russian Federation; e-mail: doctor-vma@mail.ru

Vladislav R. Khairutdinov - Dr. Sci. (Med.)., Assoc. Prof., Assoc. Prof. of the Department of Skin and Sexually Transmitted Diseases, S. M. Kirov Military Medical Academy, Ministry of Defence of the Russian Federation; e-mail: haric03@list.ru

Irena E. Belousova - Dr. Sci. (Med.)., Assoc. Prof., Prof. of the Department of Skin and Sexually Transmitted Diseases, S. M. Kirov Military Medical Academy, Ministry of Defence of the Russian Federation; e-mail: irena.belousova@mail.ru

Aleksey V. Samtsov - Dr. Sci. (Med.)., Prof., Head of the Department of Skin and Sexually Transmitted Diseases, S. M. Kirov Military Medical Academy, Ministry of Defence of the Russian Federation; e-mail: avsamtsov@mail.ru 